\title{
Effect of Different Acaricides on the Populations, of the Two-Spotted Spider Mite, Tetranychus urticae and the Leaf Miner, Liriomyza sp. and their Predators
}

\author{
Salwa M. Sholla* and M. I. A. Waheeb** \\ *Plant Protec. Res. Instit., Agric. Res. Center, Dokki, Giza, Egypt. \\ **Plant Protec. Res. Instit. Gemiza Agric. Res. Station, El-Garbia, Egypt.
}

\begin{abstract}
A field experiment was conducted to study the efficacy of the two biocides namely Vertimec ${ }^{\circledR} 18 \mathrm{EC}$ and Challenger $36 \%$ Sc and the Super-mesrona 94\%EC 9 (oil), Endo 50\% EC and Acromice (40\%), as control agents for Tetranychus urticae Koch and the leaf miner, Liriomyza sp. on three cultivars of faba bean Vicia faba (L.), sunflower and maize and their predators during the season 2012-2013. Acromic and Vertimec 18 EC enhanced the highest reduction percentage (42.2 and $40.6 \%$ ) of T. urticae on the sunflower cultivar, followed by Endo and Challenger $36 \%$ Sc after three days from treatment. On the other hand, Endo enhanced the highest reduction percentage of T. urticae on maize (62.5\%); while Endo and Challenger gave the highest reduction percentage of the predators followed by Acromic and Verttimec.
\end{abstract}

Key words: Faba bean, sunflower, maize, Tetranychus urticae, Vertimec $18 \%$ EC, Challenger, Endo EC, Super-mesrona EC, Acromice.

\section{INTRODUCTION}

Tetranychus urticae Koch represents one of the most polyphagous arthropod herbivores, feeding on different host plants. It is a major pest in green house production and field crops, destroying annual and perennial crops such as faba bean, tomatoes, peppers, sunflower and maize.

Spider mites problem increased when natural enemies are destroyed by applications of broad spectrum insecticides, applied against other pests (Mainul Haque et al., 2010). Spider mites have been rapidly developing resistance to a series of acaricides (Croft and van de Baan, 1988) and have recently assumed to a new aspect of multiple resistance (Pree et al., 2002; Van Leeuwen et al., 2004; Kim et al., 2006; Dekeyser, 2005 and Van Leeuwen et al., 2009).

To avoid these problems, it is necessary to minimize the chemical control by replacement such pesticides by using some biocides or oil with insecticides and acaricides.

So, the present work aimed to evaluate the efficacy of two common biocides (Vertimec ® 18EC and Challenger 36\% SC) Ethion (Endo 50\% EC Ethion (Endo 50\% EC Super-mesrona 94\%EC ) and Acromice (40\%) as control agents against $T$. urticae and Liriomyza sp. infesting different cultivars of faba bean Vicia faba (L.), sunflower and maize crops and their predators under field conditions.

\section{MATERIALS AND METHODS}

The present study was conducted at the farm of Gemiza Agricultural Research Station, El-Garbia governorate, Egypt, during the two successive seasons 2012 and 2013. An area of about one Feddan was divided into plots of equal size (1/200 feddan) and arranged in completely randomized blocks with three replicates for each planting.

The tested pesticides:

Five acaricides were screened for their widespread use on crops are:

1- AbamectinVertimec 18\% EC) IRAC 6; avermectin. Vertimec ${ }^{\circledR} 18 \mathrm{EC}$ - is a commercial formulation of abamectin-100 $\mathrm{cm}^{3}$ /100Liter water $+250 \mathrm{~cm}^{3}$ Oil kaby. -Vertimec ${ }^{\circledR}$

2- Chlorfenapyr (challenger 36\% SC). IRAC 13; arylpyrrole - Challenger $36 \%$ SC- is a commercial formulation of chlorfenapyr which is pyrroleacaricide - $75 \mathrm{~cm} 3 / 100$ Liter water + $250 \mathrm{~cm}^{3}$ oil kaby.

Chemichal name:

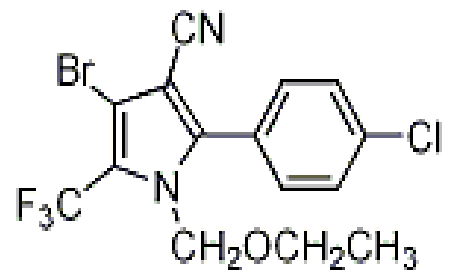

3- Ethion (Endo 50\% EC) IRAC 1B; organophosphate

Chemichal name: $S, S^{\prime}$ - methylene bis $(\mathrm{O}, \mathrm{O}-$ diethyl) phosphorodithioate.

4- Super-mesrona 94\%EC.

5- Acromice (40\%).

\section{Planting:}

The experiment was carried out during successive winter and summer seasons of 2012 and 2013. In each season, an area of about one Fadden was prepared and divided into 9 plots of about $200 \mathrm{~m}^{2}$ each. Every plot was separated from other by uncultivated two rows. The previous mentioned faba varieties were evaluated in complete randomized design. These varieties were 
obtained from Ministry of Agriculture. All faba bean seeds were sown on December $21^{\text {st }}$ and $23^{\text {rd }}$ for first and second seasons. Throughout the summer season sunflower seeds were sown in the $2^{\text {nd }}$ week of May on one side of the ridge at $20 \mathrm{~cm}$ spacing for first and second seasons.

\section{Tested acaricides on the populations of T.urticae,} Ligromyza sp. and their predators:

Each acaricide was applied at the recommended concentrations.

\section{Experimental design:}

Five experimental treatments were conducted; each was replicated three times. The replicate consisted of four lines (area for each was 0.5 meter width $\mathrm{x} 10$ meters long). The experimental design comprised complete randomized blocks.

\section{Sampling Procedure:}

Samples of ten leaves each were randomly selected biweekly from upper, midle and lower level of faba bean, sugar cane, wheat, sunflower and maize from the four treatments on the two cultivars. Samples were transferred to the laboratory to determine the number of T. urticae and the leaf miner, Liriomyza sp. stages.T. urticae and the predators were counted and recorded at pre-spraying and after 3, 7, 14 and 21 days of application; while leaf miner and Liriomyza sp. individuals were recorded at prespraying and after 3, 7, 14 and 21, 35, 45, 49, 56 and 63 days. Upper and lower surfaces of the leaves were investigated. Also, percentage of reduction was calculated for each treatment according to Henderson and Tiloton (1955).

\section{RESULTS AND DISCUSSION}

\section{Effect of the acaricides on $T$. urticae infesting faba bean:}

The results indicated that there were highly significant differences $(\mathrm{P}>0.05)$ in the reduction in population density of $T$. urticae compared between all treatments and control. Table (1), reveals that, the highest reduction percentage in population of $T$. urtice recorded $75.3 \%$ in Endo and $49.9 \%$ in Vertemic + super-masrona after 3 days of spraying.
While, after 7, 14 and 21 days the highest reduction averaged $93.2 \%$ and $83.9 \%$, respectively with Endo and Vertemic + supermasrona. On the other hand, Super-masrona recorded the lowest reduction percentage after 3 to 28 days of application, for $T$. urticae population on faba bean. These results agreed with that of Elmoghazy (2012).

The lowest reduction in T. urticae population was noted with Endo and super-masrona, respectively. (Table1).

Effect of the acaricide on reduction of $T$. urticae infesting sun flower and maize:

Results in Table (2) indicated that all treatments significantly $(\mathrm{P}>0.05)$ reduced the population of the T. urticae. Acromic and Endo enhanced the highest initial effect (42.2\% reduction) on sunflower and 62.5 $\%$ reduction on maize; while the lowest reduction was obtained with Shalnger, 33.3 and $34.2 \%$ on sunflower and maize, respectively, compared with control, after 3 days of pesticide application. While, after 7, 14 and 21 days of Endo treatment high reduction averaged 81.1, 92.7 and $94.9 \%$ were recorded on sunflower, respectively and $83.2,90.4$ and $94.7 \%$ were recorded, respectively. Also, Vertemic gave 73.4, 85.9 and 87.2 $\%$, reduction, respectively, on sun flower and 67.6, 75.6 and $80.4 \%$, respectively, for population density of $T$. urticae on maize.

On the other hand Shalinger and Acromice application led to the lowest effect on population density of $T$. urticae.

The high reduction percentage with Vertimec ${ }^{\circledR}$ $18 \mathrm{EC}$ is in agreement with Abd- Elhady and Heikal (2011) who reported that abamectin (Vertimec ${ }^{\circledR}$ 18EC) reveal recommended results to control $T$. urticae mite for 30 days after application. The lowest reduction was noted with Endo on sunflower and maize, (Table, 2).

\section{ffect of the acaricides on leaf miners infesting faba bean \\ Results presented in Table 3 revealed that the tested acaricides enhanced significant reduction percentage in leaf miner population after 3-28 days application.}

Table (1): Effect of tested pesticides on Tetranychus urticae Koch infesting faba bean plants (No. mites / square inch of leaf)

\begin{tabular}{|c|c|c|c|c|c|c|c|c|c|c|c|}
\hline \multirow{3}{*}{ Pesticides } & \multirow{3}{*}{$\begin{array}{l}\text { Rate }(\mathrm{cm})^{3} / 100 \\
\text { liter water }\end{array}$} & \multirow{3}{*}{ pretreatment } & \multicolumn{8}{|c|}{ Average number of $T$. urticae Koch } & \multirow{3}{*}{$\begin{array}{l}\text { accumulated } \\
\text { average }\end{array}$} \\
\hline & & & \multicolumn{8}{|c|}{ Days post treatment } & \\
\hline & & & $3 \mathrm{~d}$ & $\mathrm{R} \%$ & $7 \mathrm{~d}$ & $\mathrm{R} \%$ & $14 \mathrm{~d}$ & $\mathrm{R} \%$ & $21 \mathrm{~d}$ & $\mathrm{R} \%$ & \\
\hline Vertemic & $40 \mathrm{~cm}^{3}$ & 4.97 & 2.52 & 41.06 & 1.30 & 70.1 & 1.05 & 75.8 & 1.02 & 76.5 & 1.47 \\
\hline Vert+ super masrona & & 2.82 & 1.52 & 49.9 & 0.62 & 79.7 & 0.52 & 83.04 & 0.50 & 83.9 & 0.79 \\
\hline Super masrona & 1.5 lit. & 4.90 & 3.42 & 35.15 & 2.17 & 59.07 & 1.85 & 65.5 & 2.20 & 59.03 & 2.41 \\
\hline Endo & $30 \mathrm{~cm}^{3}$ & 4.77 & 1.20 & 76.3 & 0.47 & & & 90.74 & 0.35 & 93.2 & 0.63 \\
\hline Control & --- & 13.80 & 14.8 & -- & 15.07 & -- & 15.12 & -- & 15.2 & --- & 15.11 \\
\hline L.S.D. 5\% & & & 5.74 & & 6.26 & & 6.36 & & 6.38 & & ----- \\
\hline
\end{tabular}


Table (2): Effect of tested pesticides on the leaf miner Liriomyza sp. infesting faba bean plants (No. of mites / 10 leaves)

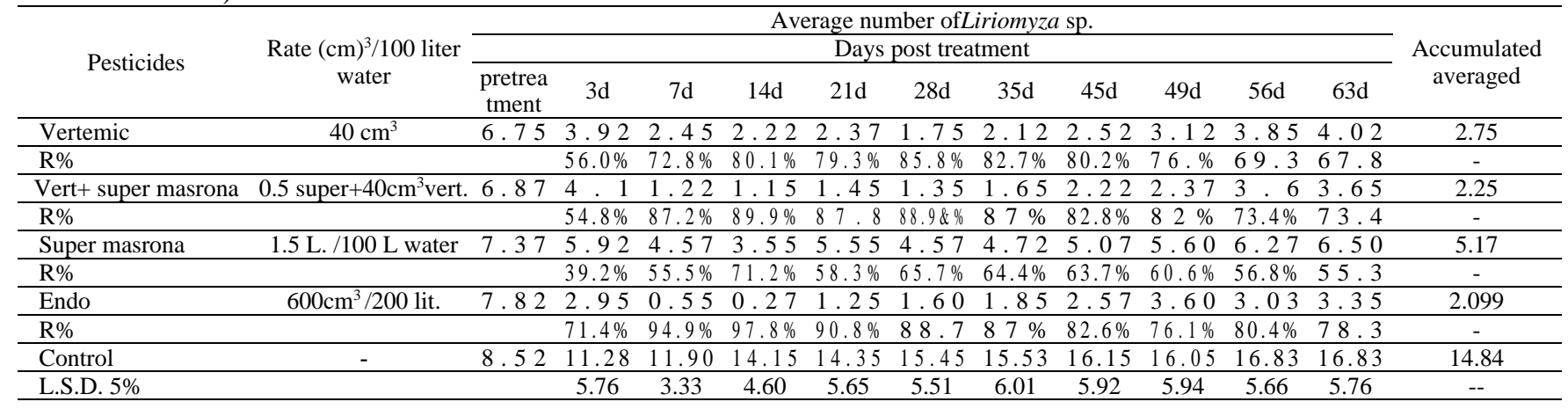

Table (3): Effect of tested pesticides on Tetranychus urticae Koch infesting sunflower and maize plants (No. mites / square inch)

\begin{tabular}{|c|c|c|c|c|c|c|c|c|c|c|c|c|}
\hline \multirow{3}{*}{\multicolumn{2}{|c|}{ Pesticides }} & \multirow{3}{*}{\multicolumn{2}{|c|}{$\begin{array}{c}\text { Rate }(\mathrm{cm})^{3} / 100 \text { liter } \\
\text { water }\end{array}$}} & \multirow{3}{*}{$\begin{array}{l}\text { pretreatm } \\
\text { ent }\end{array}$} & \multicolumn{7}{|c|}{ Average number of T. urticae Koch } & \multirow{3}{*}{$\begin{array}{l}\text { Accumulate } \\
\text { average }\end{array}$} \\
\hline & & & & & \multicolumn{5}{|c|}{ 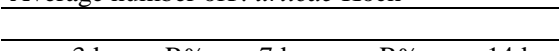 } & \multicolumn{2}{|c|}{ Days post treatment } & \\
\hline & & & & & $3 \mathrm{~d}$ & $\mathrm{R} \%$ & $7 \mathrm{~d}$ & $\mathrm{R} \%$ & $14 \mathrm{~d}$ & $\mathrm{R} \% \quad 21 \mathrm{~d}$ & $\mathrm{R} \%$ & \\
\hline \multicolumn{13}{|c|}{ Sunflower plant } \\
\hline \multicolumn{2}{|c|}{ Vertemic } & & $40 \mathrm{~cm}^{3}$ & 6.3 & 3.8 & 40.6 & 2.3 & 73.4 & 2.1 & 85.9 & 87.15 & 2.6 \\
\hline \multicolumn{2}{|l|}{ Shalnger } & & $60 \mathrm{~cm}^{3}$ & 6.2 & 4.2 & 33.3 & 2.8 & 67.6 & 2.7 & 81.6 & 84.5 & 3.07 \\
\hline \multicolumn{2}{|l|}{ Acromic } & & $40 \mathrm{~cm}^{3}$ & 5.8 & 3.4 & 42.2 & 2.6 & 67.3 & 2.5 & 81.8 & 84.1 & 2.75 \\
\hline \multicolumn{2}{|l|}{ Endo } & & $30 \mathrm{~cm}^{3}$ & 5.8 & 3.7 & 37.1 & 1.5 & 81.1 & 1.0 & 92.7 & 94.9 & 1.76 \\
\hline \multirow{2}{*}{\multicolumn{2}{|c|}{$\begin{array}{l}\text { Control } \\
\text { L.S.D. 5\% }\end{array}$}} & & - & 6.4 & 6.5 & & 8.8 & & 15.2 & 17.4 & & 11.97 \\
\hline L.S.D. $5 \%$ & & & & & 1.25 & & 2.94 & & 5.90 & 6.91 & & \\
\hline \multicolumn{13}{|l|}{ Maize plant } \\
\hline \multicolumn{2}{|c|}{ Vertemic } & & $40 \mathrm{~cm}^{3}$ & 5.0 & 3.6 & 43.8 & 2.9 & 67.6 & 2.8 & 75.6 & 80.4 & 2.97 \\
\hline \multicolumn{2}{|c|}{ Shalngersuper $24 \% \mathrm{Sc}$} & & $60 \mathrm{~cm}^{3}$ & 4.5 & 3.8 & 34.2 & 3.1 & 61.5 & 3.1 & 70.0 & 78.2 & 3.15 \\
\hline Acaromic & & & $40 \mathrm{~cm}^{3}$ & 5.2 & 3.8 & 43.0 & 3.4 & 63.5 & 3.2 & 73.2 & 77.5 & 3.37 \\
\hline Endo & & & $30 \mathrm{~cm}^{3}$ & 5.0 & 2.4 & 62.5 & 1.5 & 83.2 & 1.1 & 90.4 & 94.7 & 1.43 \\
\hline Control & & & - & 5.3 & 6.8 & & 9.5 & & 12.2 & 14.1 & & 10.65 \\
\hline L.S.D. 5\% & & & & & 1.62 & & 3.11 & & 4.39 & 5.37 & & \\
\hline $\begin{array}{r}\text { Table (4): } \\
\text { insects } \\
10 \text { leav }\end{array}$ & $\begin{array}{l}\text { : Effect } \\
\text { ts Oruis } \\
\text { aves) }\end{array}$ & $\begin{array}{l}\text { of teste } \\
\text { pp., } C\end{array}$ & $\begin{array}{l}\text { ed pesticides } \\
\text { occenella } \mathrm{sp}\end{array}$ & $\begin{array}{l}\text { Number } \\
\text { s on the } \\
\text { p. and } C\end{array}$ & $\begin{array}{l}\text { of moving } \\
\text { moving } \\
\text { hrysoper }\end{array}$ & $\begin{array}{l}\text { tages sc } \\
\text { stages } \\
\text { la car }\end{array}$ & $\begin{array}{l}\text { uare in } \\
\text { of pr } \\
\text { nea }\end{array}$ & $\begin{array}{l}\mathrm{h} \text { for leaf } \\
\text { dator } \mathrm{m} \\
\text { associate }\end{array}$ & $\begin{array}{l}\text { te } A m b l \\
\text { d with }\end{array}$ & $\begin{array}{l}\text { yseius swi } \\
\text { Faba bean }\end{array}$ & $\begin{array}{l}\text { rskii and } \\
\text { plant (No }\end{array}$ & $\begin{array}{l}\text { d predator } \\
\text { Jo. mites / }\end{array}$ \\
\hline & Rate & Pre & & & Averag & numbe & of pre & lators on fal & a bean & & & \\
\hline Pesticides & $(\mathrm{cm})^{3} / 100$ & treatm & & & & Day & post t & atment & & & & Accumulat \\
\hline & liter water & ent & $3 \mathrm{~d}$ & $\mathrm{R} \%$ & $7 \mathrm{~d}$ & $\mathrm{R}^{9}$ & & $14 d$ & $\mathrm{R} \%$ & $21 d$ & $\mathrm{R} \%$ & e average \\
\hline & & & & & Ambly. & eius swi & skii & & & & & \\
\hline Vertemic & $40 \mathrm{~cm}^{3}$ & 9 & 8 & 28 & 11 & 52. & & 12 & 48 & 12 & 66.7 & 10.75 \\
\hline Endo & $30 \mathrm{~cm}^{3}$ & 9 & 3 & 73 & 2 & 86. & & 1 & 95.7 & 1 & 97.2 & 1.75 \\
\hline Shalnger & $60 \mathrm{~cm}^{3}$ & 7 & 5 & 94.9 & 7 & 40 & & 7 & 61 & 8 & 71.2 & 6.75 \\
\hline Super masrona & $\mathrm{a} \quad 1.5 \mathrm{~L}$. & 9 & 6 & 46 & 8 & 46. & & 7 & 69.7 & 7 & 80.5 & 7 \\
\hline Acromic & $40 \mathrm{~cm}^{3}$ & 8 & 7 & 29.1 & 7 & 47. & & 9 & 56.1 & 12 & 62.5 & 8.75 \\
\hline Control & - & 9 & 11 & & 15 & & & 23 & & 36 & & 21.25 \\
\hline L.S.D. 5\% & & & 2.73 & & 4.36 & & & 7.38 & & 12.12 & & \\
\hline & & & & & & uis spp. & & & & & & \\
\hline Vertemic & $40 \mathrm{~cm}^{3}$ & 18 & 15 & 20.8 & 18 & 24 & & 21 & 38.2 & 22 & 48.7 & 19 \\
\hline Endo & $30 \mathrm{~cm}^{3}$ & 16 & 3 & 82.1 & 2 & 90. & & 1 & 96.7 & 1 & 97.4 & 1.75 \\
\hline Shalnger & $60 \mathrm{~cm}^{3}$ & 15 & 9 & 43 & 12 & 39. & & 13 & 56.9 & 13 & 63.6 & 14.75 \\
\hline Super masrona & a $1.5 \mathrm{~L}$. & 16 & 11 & 34.7 & 14 & 33. & & 14 & 53.6 & 15 & $60.6 \%$ & 13.5 \\
\hline Acromic & $40 \mathrm{~cm}^{3}$ & 18 & 12 & 36.6 & 15 & 36. & & 16 & 52.9 & 17 & 60.3 & 15 \\
\hline Control & - & 19 & 20 & & 25 & & & 36 & & 45 & & 31.5 \\
\hline L.S.D. 5\% & & & 5.71 & & 7.55 & & & 11.47 & & 14.59 & & \\
\hline & & & & & carnea & Chrysol & erla & & & & & \\
\hline Vertemic & $40 \mathrm{~cm}^{3}$ & 23 & 22 & $4.34 \%$ & 29 & 31.9 & & 30 & $37.4 \%$ & 35 & $42.1 \%$ & 29 \\
\hline Endo & $30 \mathrm{~cm}^{3}$ & 24 & 5 & $79.1 \%$ & 4 & $91^{c}$ & & 2 & $96 \%$ & 1 & $98.4 \%$ & 3 \\
\hline Shalnger & $60 \mathrm{~cm}^{3}$ & 23 & 9 & $60.9 \%$ & 11 & 74.2 & & 15 & $68.6 \%$ & 12 & $80 \%$ & 11.75 \\
\hline Super masrona & a $1.5 \mathrm{~L}$. & 22 & 22 & $28 \%$ & 15 & 63.1 & & 16 & $95 . .1 \%$ & 19 & $67.2 \%$ & 18 \\
\hline Acromic & $40 \mathrm{~cm}^{3}$ & 24 & 16 & $33.3 \%$ & 19 & 57.3 & & 20 & $68 \%$ & 22 & $65.2 \%$ & 19.25 \\
\hline Control & - & 25 & 35 & & 46 & & & 52 & & 65 & & 19.25 \\
\hline L.S.D. 5\% & & & 10.72 & & 14.94 & & & 17.03 & & 22.3 & & \\
\hline & & & & & spp. & Coccene & & & & & & \\
\hline Vertemic & $40 \mathrm{~cm}^{3}$ & 38 & 36 & $5.3 \%$ & 35 & 27. & & 25 & $67.1 \%$ & 25 & $71.7 \%$ & 30.25 \\
\hline Endo & $30 \mathrm{~cm}^{3}$ & 39 & 6 & $84.8 \%$ & 4 & 91. & & 2 & $97.4 \%$ & 1 & $98.8 \%$ & 3.25 \\
\hline Shalnger & $60 \mathrm{~cm}^{3}$ & 35 & 15 & $57.1 \%$ & 11 & 75 . & & 11 & $84.3 \%$ & 9 & $88.9 \%$ & 11.5 \\
\hline Super masrona & a $1.5 \mathrm{~L}$. & 29 & 19 & $34.5 \%$ & 22 & 40 & & 15 & $74.1 \%$ & 15 & $77.5 \%$ & 17.75 \\
\hline Acromic & $40 \mathrm{~cm}^{3}$ & 39 & 25 & $35.9 \%$ & 27 & 45. & & 15 & $80.8 \%$ & 16 & $83.4 \%$ & 20.75 \\
\hline Control & - & 39 & 39 & & 49 & & & 77 & & 89 & & 63.5 \\
\hline L.S.D. 5\% & & & 7.26 & & 9.17 & & & 5.4 & & 6.00 & & \\
\hline
\end{tabular}


After then, the reduction percentage decreased gradually until 63 days after treatment. Endo showed the highest initial effect $(71 \%$ reduction $)$ in population density of the leaf minor on faba bean, after 3 days of treatment; while the highest reduction percentage was recorded with Vertemic after 28 days (85.8\% reduction). On the other hand application of Vertemic + super-masrona, super-masrona and Endo revealed high reduction percentage after 14 days (89.9, 71.2 and $97.8 \%$, respectively) on faba bean compared with control.

The lowest accumulated mean was 2.099 individuals of moving stages/square inch compared with 14.849 of moving stages.

\section{Effect of the acaricides on predators:}

Data presented in table 4 showed that all acaricides treatments significantly reduced the population of the predators; Endo had the highest initial effect $(84.8 \%, 82.1 \%, 79.1 \%$ and $73 \%$ reduction) for coccenella spp., Oruis spp., Chrysoperla carnea Stephen and Amblyseius swirskii Athias-Henriot, respectively. The lowest effect was obtained with Vertemic 4.34, 5.3\%, 20.8\% and 28\% for C. carnea,coccenella spp. Oruis spp. and A.swirskii, respectively, after 3 days of treatment. While, after 7, 14 and 21 days of treatment Endo recorded the highest reduction; while Vertemic revealed the lowest

\section{REFERENCES}

Abd-Elhady, H. K. and Heikal,H. M. M. 2011. Selective toxicity of three acaricides to the two spotted spider mite Tetranychus urticae and predatory mite Phytoseuilus persimilis in apple orchards. Journal of Entomology, 8: 574-580.

Croft, B. A. and van de Baan, H. E. 1988. Ecological and genetic factors influencing evolution of pesticide resistance in tetranychid and phytoseiid mites. Exp. Appl. Acarol., 4: 277-300.

Dekeyser, M. A. 2005. Acaricide mode of action. Pest Manag. Sci. 61, 103e, 110.

Elmoghazy M. M. E.; El-Saiedy E. M. A. and Romeih, A. H. M. 2012. Integrated control of the two spotted spider mite Tetranychus urticae Koch (Acari: Tetranychidae) on faba bean (L.) in an open field at Behaira governorate. Egypt International Journal of Environmental Science and engineering, 2: 93-100.

Kim, Y.; Park, H.; Cho, J. and Ahn, Y. 2006. Multiple resistance and biochemical mechanisms of pyridaben resistance in Tetranychus urticae (Acari: Tetranychidae). J. Econ Entomol., 99: $954-958$.

Henderson, C. F. and Tilton, E. W. 1955. Test with acaricides against the brown wheat mite. J. Econ. Entomol., 48: 157-161.

Mainul Haque, M.; Ali, A., and M. Parvin 2010. Voracity of three predators on two-spotted spider mite, Tetranychus urticae Koch (Acari: Tetranychidae) and their developmental stages. Research Journal of Agriculture and Biological Sciences, 6(1): 77-83.

Pree, D. J., Bittner, L. A. and Whitty, K. J. 2002. Characterization of resistance to clofentezine in populations of European red mite from orchards in Ontario. Exp. Appl.Acarol., 27:181- 193.

Van Leeuwen, T.; Stillatus, V. and Tirry, L. 2004. Genetic analysis and cross- resistance spectrum of a laboratory selected chlorfenapyr resistant strain of two-spotted spider mite (Acari: Tetranychidae). Exp. Appl. Acarol., 32:249-261. 